\title{
EKSISTENSI TARI BEDHAYA KETAWANG
}

\author{
Supriyanto \\ Program Studi Seni Tari Fakultas Seni Pertunjukan \\ Institut Seni Indonesia (ISI) Surakarta \\ Email: ekosupriyanto@isi-ska.ac.id
}

\begin{abstract}
Bedhaya Ketawang dance is a dance developed in the Surakarta Palace. This dance in ancient times should only be performed when Jumenengan sinuwun. The development of this dance can then be danced outside the palace walls. The problem in this study is how the philosophical values contained in the Bedhaya Ketawang Dance and how the existence of the Bedhaya Ketawang Dance existed in the past with the present. The benefits of this research are entitled Philosophical Values in Bedhaya Ketawang Dance (Its existence in the past with the present) is to find philosophical values in the Bedhaya Ketawang Dance and see its existence in the past with the present. Research on Philosophical Values in Bedhaya Ketawang Dance is a type of library research. Library research is a study carried out by examining a number of libraries that are used as references. The results of this study are the philosophical values contained in the Bedhaya Ketawang Dance and the existence of the existence of the Bedhaya Ketawang Dance in the past with the present.
\end{abstract}

Keywords: Bedhaya Ketawang, philosophy, existence, shift

\section{A. PENDAHULUAN}

Sebuah tarian tidak hanya sebagai suatu bentuk gerak dan ekspresi dari seorang penari. Akan tetapi dalam satu tarian terkandung makna filosofis yang beragam. Seperti halnya Tari Bedaya Ketawang yang memiliki nilai-nilai filosofis seperti jawa, rasa cinta, keindahan, dan sebagainya. Nilai-nilai ini seiring dengan perkembangan waktu mengalami pergeseran yang cukup signifikan di masa sekarang. Baik itu dari segi fungsi, ritual, penyajian sudah mulai adanya pergeseran. Tentunya ini merupakan dinamika yang harus dihadapi oleh para seniman. Tetapi, hal yang terpenting adalah masih tetap dipertahankan eksisitensinya di masa kini dan masa mendatang. Bedhaya Ketawang masih ditarikan baik di dalam kraton maupun di luar tembok kraton.

Penelitian tentang nilai-nilai filosofis dalam Bedaya Ketawang menarik untuk dilakukan penelitian. Karena, banyak nilai filosofis yang terkandung dalam tarian ini. Selain itu, eksistensinya pada masa lampau dengan masa sekarang menjadi hal yang menarik untuk dikaji. Hal ini menginggat seni tari mulai tergeser dengan tarian modern yang berasal dari luar negeri. Meskipun, sudah berusaha tetap melestarikan dan mempertahankan eksistensi budaya-budaya lokal akan tetapi keberadaan budaya barat menjadi tantangan yang menarik untuk diteliti.

Siska Ratna Sari (2010) dalam Skrispsi yang berjudul Bedhaya Ketawang (Studi Nilai Filosofofis Tari Bedhaya Ketawang) dalam penelitian ini adalah membahas tentang (1) Latar Belakang Tari Bedhaya Ketawang menjadi tarian suguhan yang sakral, (2) Nilai 
- nilai yang Terkandung dalam Tari Bedhaya Ketawang, (3) Pergeseran Tari Bedhaya Ketawang dimasa sekarang.

Tuti Hariyani (2007) dalam skripsi yang berjudul Pergeseran Makna Tari Bedhaya Ketawang di Keraton Surakarta Hadiningrat Dari Tahun 1920-2005 meneliti tentang Pergeseran atau perubahan merupakan sesuatu yang selalu akan terjadi dalam setiap masyarakat. Tidak terkecuali Keraton Surakarta Hadiningrat. Seiring dengan perkembangan zaman, Keraton Surakarta tidak lagi memiliki kekuasaan dalam pemerintahan. Keraton Surakarta sebagai penerus negara Mataram yang pada zaman dulu menguasai perpolitikan di Nusantara, kini statusnya telah berubah menjadi salah satu wilayah NKRI dan hanya berfungsi sebagai tempat pengembangan kebudayaan. Berubahnya fungsi keraton membawa juga terhadap segala sesuatu yang ada di dalamnya termasuk tari Bedhaya Ketawang. Tari Bedhaya Ketawangmerupakan hasil dari kebudayaankeraton Surakarta Hadiningrat. Tari Bedhaya Ketawangmenceritakan kisah percintaan antara Susuhunan dengan Kanjeng Ratu Kidul. Tari Bedhaya Ketawang yang dulu merupakan lambang kebesaran Mataram, kini hanya sebagai warisan budaya yang keberadaannya harus dijaga kelestariannya.

Studi terhadap kesenian klasik Jawa, merupakan bentuk revitalisasi nilai-nlai ajaran budaya Jawa dalam menemukan jati-diri bangsa sebagai identitas budaya Jawa yang Indonesia. Memahami kesenian klasik Jawa, akan berkaitan tentang makna, nilai, dan simbol, yang dijadikan acuan oleh sekelompok masyarakat pendukungnya. Kemudian akan menjadi acuan dan pedoman bagi kehidupan masyarakat dan sebagai sistem simbol, pemberian makna, model yang ditransmisikan melalui kode-kode simbolik. Pengertian seni klasik tersebut memberikan konotasi, bahwa seni merupakan ekspresi kebudayaan masyarakat, berupa hasil gagasan dan tingkah laku manusia dalam komunitasnya. Artefak seni yang lahir di Bumi Nusantara (Jawa), merupakan ekspresi kebudayaan masyarakatnya dengan segala falsafah dan filsafat yang melatar belakanginya. Studi tentang fenomena ini akan mencoba memahami tentang estetika nusantara (Jawa), sebagai dasar untuk mengkaji kesenian tradisi klasik, yang selama ini dianggap tidak punya "paugeran" (paradigma yang diyakini) terhadap karya-karya seni klasik (Dharsono 2014:11).

Berkaitan dengan persolaan tari klasik Jawa yang mulai mengalami perubahan di berbagai hal maka hal ini tidak jauh pula dengan keberadan tari Bedhaya Ketawang. Tari Bedhaya Ketawang mengalami proses perubahan di berbagai hal. Tari yang semula hanya boleh dipertunjukan di kraton pada even tertentu. Maka, untuk sekarang ini boleh dipentaskan di luar tembok kraton. Begitupula dengan acara ritual yang mulai berbeda, durasi pertunjukan, ketentuan penarinya, dan sebagainya.

Berkaitan dengan itu, Maryono (2012: 3) menjelaskan bahwa tari pada dasarnya merupakan perpaduan dari beberapa unsur yang paling dasar atau elementer dari cabang-cabang seni, diantaranya gerak tubuh sebagai media garap tari, bunyi dan bahasa sebagai media garap iringan, serta seni rupa yang diaktualisasikan lewat media garap rias dan busana, yang kesemuanya direalisasikan kemunculannya secara komplementer. Penafsiran terhadap keragaman media komunikasi yang terdapat dalam tari tidak mampu hanya ditangkap secara rasional semata tetapi ketajaman rasa, pikir, dan institusi merupakan ujung tombak dalam menangkap makna yang sebenarnya.

Berkaitan dengan itu, Wiedyastutiningrum (2014:62) menjelaskan bahwa dalam meyajikan karya atau susunana tari, sangat memperhatikan pula virtuositas ketrampilan teknik yang masih merupakan andalan dan bahan pemeran utama. Tentu saja dalam hal ini postur tubuh juga sangat dipertimbangkan sebagai modal kekuatan yan alami guna menghasilkan sebuah 
karakteristik yang unik. Ada dua faktor yang perlu dipersiapkan untuk menyajikan suatu koreografi yaitu fisik dan nonfisik. Faktor fisik meliputi persiapan ragawi yang menentukan dalam kehadiran sebuah ekspresi. Persiapan tubuh dapat dicapai dengan kematangan latihan yang kontinu. Ada dua faktor yang perlu dipersiapkan untuk menyajikan suatu koreografi yaitu fisik dan non fisik.

Penelitian tentang Nilai-Nilai Filosofis Dalam Tari Bedhaya Ketawang ini merupakan jenis penelitian pustaka. Penelitian pustaka merupakan suatu penelitian yang dilakukan dengan menelaah sejumlah pustaka yang menjadi acuannya. Sumber pustaka dapat berupa buku, jurnal, makalah, hasil penelitian yang sudah ada, maupun internet. Penelitian juga dapat dilakukan dengan mengkaji penelitian yang sudah dilakuakan orang lain. Penelitian pustaka bisa menjadi pijakan untuk mengembangkan penelitian menjadi sebuah buku referensi. Penelitian pustaka dapat dikategorikan penelitian ilmiah.

\section{B.NILAI-NILAI FILOSOFIS DALAM BEDHAYA KETAWANG}

Keraton menjadi tempat yang melahirkan banyak budaya. Budaya-budaya tersebut menjadi berkembang di masyarakat. Salah satunya kesenian Tari. Tari dilahirkan dan dikembangkan dari kraton. fungsi tari menjadi sesuatu yan tidak hanya sekedar sebai hiburan tetapi tari sebagai salah satu bentuk yang diunakkan dalam suatu yang mengiringi peristiwa dalam kraton. Kraton menjadi sumber inspiransi dari berkembangnya kesenian baik yang ada di dalam tembok maupun yang ada dalam tembok. Seiring perkembangan waktu budaya-budaya yang dahulunya hanya boleh dilakukan di dalam tembok kraton sekarang sudah boleh dilakukan oleh masyarakat yang ada di luar tembok. Tentunya ini menjadi hal yang mendorong lahirnya akulturasi dengan budaya luar. Proses akulturasi merupakan suatu proses yang alamiah akan merambat masuk ke dalam sebuah negara. Dan, tidak bisa dihindari keberadaannya akan tetapi bisa difilterisasi.

Keberadaan tari-tari tradional yang lahir dan besar di dalam kraton tentunya akan terus dijaga eksistensinya. Namun tidak semuanya bisa terjaga. Ada yang sudah mengalami perubahan atau justru sudah timbul tenggelam. Beberapa tari tardisonal yang masih eksis sering dijumpai dalam berbagai event adalah tari Bedhaya. Tari Bedhaya kemudian berkembang menjadi beberapa jenis bedhaya.

Berbicara tentang sebuah filosofi tentang suatu hal tentunya memerlukan sebuah perenungan, penghayatan, bahkan sampai pada sebuah reseach. Sebuah karya tercipta akan berujung pada nilai filosofinya. Begitupula dengan sebuah tarian. Sebuah tarian tidak hanya tercipta begitu saja tanpa ada sesuatu dan memiliki sesuatu. Begitu sebuah tarian tercipta maka lahirlah nilai-nilai filosofinya. Tinggal bagaimana seorang penikmat mampu menghayati nilai filosofinya. Begitupula dengan keberadaan tari Bedhaya Ketawang. Tari ini begitu populer dari masa ke masa. Bahkan mengalami inovasi pada beberapa hal. Meskipun demikian, eksistensinya masih begitu kuat. Hal ini dibuktikan dengan seringkali pada event-event tertentu masih menggunakan tarian ini dengan begitu elegan. Balutan busana dan riasanya menjadi sesuatu yang membuat orang betah untuk melihatnya sampai pertunjukan berakhir. Durasi waktunya yang kemudian seringkali diringkas menjadi sedikit lebih pendek. Hal ini disesuaikan dengan acara yang digelar.

Tari Bedhaya Ketawang mengenakan bobot ageung bangun tulak sebagai salah satu cirinya. Bentuk dodot bangun tulak ini merupakan perwujudan kesadaran akan perlindungan. Ini tampak dengan warna khas pakaian dodot bangun tulak yaitu hijau biru tua dengan warna putih merupakan simbol daya hidup, berkembangnya hidup dari kuasa Tuhan, merupakan sinar putih sebagai asal mula hidup. Warna biru merupakan simbol budi, arif 
bijaksana, waspada, keimanan, keteguhan hati dalam perjuangan dan pengabdian. Motif alasalasan merupakan perwujudan dengan Tuhan (Haryonagoro, 5 Oktober 2001).

Bedaya Ketawang bukan suatu tarian yang semata-mata untuk tontonan, karena tari ini hanya ditarikan untuk sesuatu yang khusus dalam suasana yang resmi sekali. Seluruh suasana jadi sangad khudus, sebab tarian ini hanya dipergelarkan berhubungan berhubungan dengan peringatan ulang tahun tahta kerajaan saja. Jadi tarian ini hanya sekali setahun dipergelarkannya Selama tarian berlangsung tiada hidangan keluar, juga tidak dibenarkan orang merokok. Makanan, minuman atau pun rokok dianggap hanya akan mengurangi kekhidmatan jalannya upacara adat yang suci ini.

Bedhaya Ketawang ini dipandang sebagai suatu tarian ciptaan Ratu diantara seluruh mahluk halus. Bahkan orang pun percaya bahwa setiap kali Bedhaya Ketawang ditarikan, sang pencipta selalu hadir selalu hadir juga serta ikut menari. Tidak setiap orang dapat melihatnya, hanya pada mereka yang peka saja sang pencipta menampakkan diri. Konon dalam latihan-latihan yang dilakukan, serig pula sang pencipta ini membetul-betulkan kesalahan yang dibuat oleh para penari. Bila mata orang awam tidak melihatnya, maka penari yang bersangkutan saja yang merasakan kehadirannya.Dalam hal ini ada dugaan, bahwa semula Bedhoyo Ketawang itu adalah suatu tarian di candi-candi.

Tari Bedhaya Ketawang merupakan sebuah tarian yang dipopulerkan di Keraton Surakarta. Meskipun pada awalnya menurut beberapa sumber Bedhaya Ketawang berasal dari Yogyakarta. Dalam Perjanjian Giyanti disepakati bahwa Kerajaan Mataram menjadi Kasunanan Surakarta dan Kasultanan Yogyakarta. Keraton Surakarta menginginkan Tari Bedhaya Ketawang sebagai salah satu pertunjukan sakral di istana. Sedangkan Keraton
Yogyakarta, mencipta Bedhaya Semang. Bedhaya Semang merupakan sebuah tarian kebesaran yang hanya boleh dipertunjukkan pada saat penobatan serta Tingalandalem Jumenengan Sunan Surakarta (upacara peringatan kenaikan tahta raja).

Nama Bedhaya Ketawang diambil dari kata bedhaya yang artinya penari wanita di istana. Sedangkan ketawang sendiri berarti langit. Langit digambarkan dengan sesuatu yang tinggi, keluhuran, dan kemuliaan. Dalam Kamus Besar Bahasa Indonesia langit dideskripsikan sebagai ruang luas yang terbentang di atas bumi, tempat beradanya bulan, bintang, matahari, dan planet lainnya (2008: 561). Tari Bedhaya Ketawang kemudian menjadi tarian sakral yang suci karena menyangkut Ketuhanan. Filosofi dalam arti ini memberi makna bahwa segala sesuatu tidak akan terjadi tanpa kehendak Tuhan Yang Maha Esa. Tari Bedhaya Ketawang dibawakan oleh 9 penari wanita. Ada aturan ketika seorang penari membawakan Bedhaya Ketawang. Wanita tersebut harus masih gadis dan dalam keadaan suci. Bergesernya waktu kemudian penari Bedhaya Ketawang boleh ditarikan oleh wanita yang di luar syarat tersebut tetapi dengan meminta ijin dahulu. Tarian ini masih berbau magis. Bedhaya Ketawang embrio dari jenis tari Bedhaya lainnya. Setelah Bedhaya Ketawang kemudian lahirlah bedhaya-bedhaya yang lain. Ada Bedhaya Semang, Bedhaya Sabda Aji, . Bedhaya Angron Sekar, Bedhaya Herjuna Wiwaha, Bedhaya Sumreg, Bedhaya Sang Amurwabhumi, Bedhaya Pangkur, Bedhaya Duradasih, Bedhaya Mangunkarya, Bedhaya Sinom, Bedhaya Endhol - Endhol, Bedhaya Gandrungmanis, Bedhaya Kabor, Bedhaya Ela-Ela.

Berbicara tentang sebuah tarian tentunya merupakan hal yang tidak terlepas dari sebuah teori yang mendasari terbentuknya sebuah tarian. Begitupula dengan Tari Bedhaya Ketawang yang merupakan jenis Tari Jawa. Tari Bedhaya Ketawang berasal 
dari Keraton Yogyakarta. Tarian ini kemudian dikembangkan di Kraton Surakarta. Tarian ini merupakan sebuah tarian yang sakral dan hanya bisa ditarikan pada event tertentu pada saat itu. Tariannya mengandung banyak nilai filosofis yang dapat dijabarkan menjadi makna dalam kehidupan.

Keseluruhan penari yang berjumlah 9 orang dipercaya merupakan angka sakral yang melambangkan 9 arah mata angin. Hal ini sesuai dengan kepercayaan masyarakat Jawa pada peradaban Klasik, dimana terdapat 9 dewa yang menguasai sembilan arah mata angin yang disebut juga sebagai Nawasanga, yang terdiri dari: Wisnu (Utara), Sambu (Timur Laut), Iswara (Timur), Mahesora (Tenggara), Brahma (Selatan), Rudra (Barat Daya), Mahadewa (Barat), Sengkara (Barat Laut), dan Siwa (Tengah). Upaya mengejawantahkan 9 dewa penguasa arah mata angin dalam wujud 9 orang penari tersebut merupakan suatu simbol bahwa pada hakekatnya tari Bedhaya Ketawang bertujuan untuk menjaga keseimbangan alam yaitu keseimbangan antara mikrokosmos (jagat kecil) dan makrokosmos (jagat besar). Suatu konsep kosmologi yang telah mendarah daging pada masyarakat Jawa sejak berabad-abad silam. Kesembilan penari tersebut memiliki posisi masing-masing yang disebut sebagai batak, endhel ajeg, endhel weton, apit ngarep, apit mburi, apit meneng, gulu, dhadha, serta boncit. Masing-masing posisi merupakan suatu simbol, yaitu: (a). Apit mburi: melambangkan lengan kiri, (b). Apit ngarep : melambangkan lengan kanan,(c) Apit meneng:melambangkan kaki kir , (d) Batak :mewujudkan jiwa dan pikiran, (e) Buncit : mewujudkan organ sek, (f) Dadha : melambangkan dada, (g) Endhel ajeg:mewujudkan nafsu atau keinginan hati, (h) Endhel weton: melam bangkan kaki kanan, (i) (Jangga) gulu: melambangkan leher (http:// marienthahera.blogspot.co.id/2013/12/taribedhaya-ketawang.html).

Berkaitan dengan itu, Soedarsono (1984:79-82) menjelaskan bahwa jumlah sembilan penari pada tari Bedhaya juga merupakan simbol mikrokosmos (jagading manungsa) yang ditandai dengan adanya sembilan lubang yang ada manusia. Jumlah sembilan penari juga menunjukkan peran ynag dibawakan oleh setiap penari, masing-masing: penari batak sebagai kepala, yang merupakan perwujudan dari pikiran dan jiwa; penari edhel ajeg merupakan perwujudan bagian leher; penari dhaha mewujudkan bagian dada; penari apit ngajeng mewujudkan bagian lengan kanan; penari apit wingking mewujudkan bagian lengan kiri; penari edhel weton mewujudkan bagian tungkai kanan; penari apit meneng/ kendhel mewujudkan bagian tungkai kiri; penari buncit mewujudkan bagian organ seks.

Berikut ini gambar pertunjukan Tari Bedhaya Ketawang

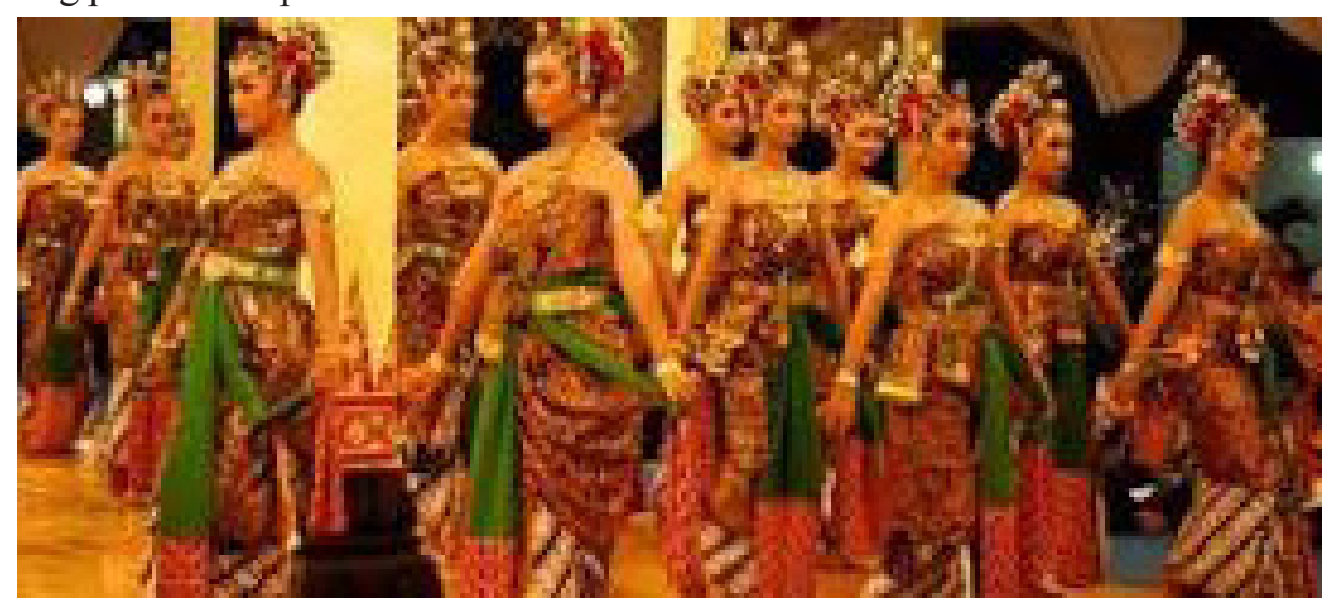

(https://www.google.co.id/ search?q=gambar+penari+bedhaya+ketawang) 


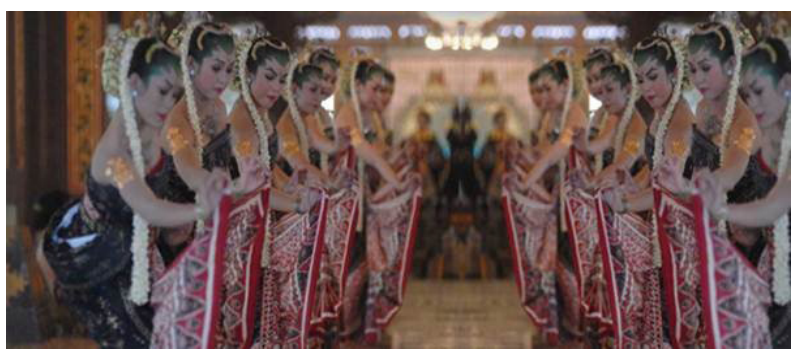

Tarian Bedhaya Luluh (https://www. google.co.id/search)

Tari Bedhaya Ketawang adalah bentuk tarian yang tumbuh dan berkembang di lingkungan keraton Kasunanan Surakarta, merupakan satusatunya tarian yang berfungsi ritual karena hanya disajikan pada upacara Jumenengan maupun Tingalandalem Jumenengan Raja. Penari Bedhaya Ketawang yang berasal dari putri-putri kerabat keraton menjadi sedikit, sehingga tahun 1980 pihak keraton membuka peluang bagi penari-penari luar keraton sebagai penyaji tari Bedhaya Ketawang adalah hal yang melatar belakangi penelitian ini.

Tata rias juga menjadi kunci dalam pementasan sebuah tarian. Tata rias yang sesuai dengan karakter tari yang dibawakan menjadi hal yang menambah keindahan dari tarian tersebut. Maka seorang perias pun harus dapat merias sesuai dengan karakter dari tarian tersebut. Tata rias dalam Tari Bedhaya Ketawang adalah riasan pengantin Jawa. Gambar Paes terdiri dari empat bagian gajah, pangapit,panitis, dan godheg. Pengantin Jawa memiliki riasan yang elegan. Sampai sekarang banyak yang masih menggunakan rias manten model pengantin Jawa dengan gaya Surakarta. Ada yang hanya model basahan atau memakai kebaya yang berwarna hitam. Model ini masih banyak digunakan meskipun sudah dimodifikasi dengan berbagai hiasan yang elegan. Ada juga yang model di kepala dengan hijab tidak berupa sanggul atau gelung konde. Tetapi masih terlihat identitas sebagai pengantin Jawa.

Menurut sejarahnya, tari Bedhaya dalam pelembagaannya merupakan tari klasik yang sangat tua usianya dan merupakan kesenian asli Jawa. Tari Bedhaya yang tertua adalah Bedhaya Semang yang diciptakan oleh Hamengku Buwono I pada tahun 1759, dengan cerita perkawinan Sultan Agung dari Mataram dengan Ratu Kidul yang berkuasa di samudera Indonesia. Pelembagaan tari Bedhaya Semang ini dianggap sakral karena perkawinan tersebut dianggap sebagai hubungan suci. Karena kesakralannya itulah, maka Bedhaya Semang menjadi pusaka kraton yang sangat dikeramatkan. Sebagai sebuah genre tari, spesifikasi Bedhaya antara lain, adalah pertama, ditunjukkan dengan penggunaan penari putri yang pada umumnya berjumlah sembilan dan mempergunakan rias busana yang serba kembar. Kedua, Bedhaya sebagai salah satu genre tari Jawa, telah dijadikan sumber referensi dalam penyusunan gerak tari putri di keraton Yogyakarta. Ketiga, tari Bedhaya memiliki muatan makna simbolik dan filosofis yang tinggi dan dalam, sehingga menjadi contoh yang paling tepat bagi cara penerapan konsep alus-kasar dalam tari Jawa (Pudjasworo 1993:2).

Tari Bedhaya Ketawang diiringi dengan tembang yang menggambarkan curahan hati kangjeng ratukidul kepada sang raja. Padabagian pertama tarian diiringi dengan tembang Durma, kemudian di lanjutkan dengan RatnamulyaTari Bedhaya Ketawang dalam setiap pementasannya selalu diiringi musik gending ketawang gedhe dengan nada pelog. Dalam hal ini, menggunakan instrumen kethuk, kenong, gong, kendhang dan kemanak. Dalam pertunjukan Tari Bedhaya Ketawang di bagi menjadi tiga babak (adegan). Di tengah tarian nada gendhing berganti menjadi slendro selama 2x. Setelah itu nada gending kembali lagi ke nada pelog hingga tarian berakhir. Selain di iringi oleh musik gending. Pada saat penari masuk kembali ke dalem ageng prabasuyasa, instrument musik di tambahkan dengan gambang, rebab, gender dan suling untuk menambah keselarasan suasana..

Busana yang digunakan penari dalam pertunjukan Tari Bedhaya Ketawang 
adalah busana yang digunakan oleh para pengantin perempuan jawa, yaitu Dodot Ageng atau biasa di sebut Basahan. Pada bagian rambut menggunakan Gelung Bokor Mengkurep, yaitu gelungan yang ukurannya lebih besar dari gelungan gaya Yogyakarta. Untuk aksesoris perhiasan yang di gunakan diantranya adalah centhung, garudha mungkur, sisir jeram saajar, cundhuk mentul, dan tiba dhadha (rangkaian bunga yang di kenakan pada gelungan, yang memanjang hingga dada bagian kanan).

\section{EKSISTENSI KEBERADAAN TARIAN BEDHAYA KETAWANG DI MASA LAMPAU DENGAN MASA SEKARANG INI}

Berkembangnya waktu dan adanya pengaruh akulturasi, Tari Bedhaya Ketawang mengalami pergeseran di berbagai dimensi. Baik dari upacaranya, waktu pertunjukan, busana, tingkat kesakralan, dan ketentuan penarinya. Akan tetapi, eksistensinya masih mengakar di masyarakat kota Surakarta. Pertunjukan Tari bedhaya Ketawang masing eksis di acara-acara yang resmi di berbagai event baik yang berbau budaya ataupun di luar budaya. Melihat dari hal ini, upaya preventif perlu dilakukan agar tari Bedhaya Ketawang masih eksis diberbagai jaman. Tari Bedhaya ketawang merupakan aset budaya yang tidak ternilai maka perlu dijaga kelangsungannya.

Ada tari Bedhaya yang belum berubah antara lain Bedhya Ketawang (130 menit), Bedhaya Pangkur (60 menit), Bedhaya Duradasih (60 menit), Bedhaya Mangunkarya (60 menit), Bedhaya Sinom (60 menit), Bedhaya Endhol-Endhol (60 menit), Bedhaya Gandrungmanis (60 menit), Bedhaya Kabor (60 menit), dan Bedhaya Tejanata (60 menit). Tari Bedhaya diciptakan kemudian menggunakan durasi waktu antara 10-15 menit. Tari Bedhaya ciptaan baru menghilangkan gerak-gerak yang diulang, memadatkan isi kesan, dan memperhatikan aspek estetika gerak (Suharji,
2010:40)

Setiap tari Bedhaya ketawang akan digelar, baik pada saat latihan maupun Tingaladalem Jumenengan, parapenariakanselalumemberikan 22 sesaji yang ditujukan untuk Kanjeng Ratu Kidul. Kehidupan keagamaan di kalangan keraton selain percaya dan menghubungkan sesuatu dengan Yang Maha Kuasa atau Tuhan, mereka masih masih percaya dengan adanya mahluk-mahluk halus penjelmaan nenek moyang yang sudah meninggal, adanya roh-roh penjaga (bahureksa), adanya setan, hantu atau kekuatan-kekuatan gaib dalam alam semesta. Keyakinan-keyakinan seperti ini dapat dilihat pada peristiwa-peristiwa seperti caos dhahar yaitu suatu manifestasi dari kebaktian dan usaha berkomunikasi dengan mahluk halus dan dunia gaib. Caos dhahar banyak dilakukan oleh masyarakat kalangan keraton, lebih-lebih mereka yang masih mempunyai hubungan erat dengan keraton seperti abdi dalem atau kerabat keraton. Caos dhahar dilakukan pada hari-hari tertentu dan pada tujuan-tertentu pula. Hari hari yang biasa dilakukan untukcaos dhahar biasanya hari Kamis malam Jum'at, malam Selasa Kliwon (Anggara Kasih) atau malam Jum'at Kliwon. Maksud caos dhahar bisa ditujukan pada Penguasa Laut Selatan atau Kanjeng Ratu Kencanasari untuk mohon keselamatan atau kesejahteraan ( Supriyanto dalam Jurnal Harmonia, 2001: 30-31).

Bedhaya Ketawang adalah tarian yang mengandung makna dan sifat tertentu. Menurut K.G.P.H Hadiwidjojo (1978:12-15), makna dan sifat Bedhaya Ketawang sangat erat hubungannya dengan :

1.Adat upacara

Bedhaya Ketawang jelas bukan suatu tarian untuk tontonan samata-mata, karena hanya dipergelarkan untuk sesuatu yang khusus dan dalam suasana yang resmi sekali. Seluruh sesuatu menjadi sangat khudus sebab tarian ini hanya dipergelarkan pada peringatan ulang tahun tahta kerajaan saja. Jadi tarian ini hanya sekali setahun dipergelarkan. Selama 
tarian berlangsung tidak ada hidangan keluar. Makanan dan minuman hanya akan mengurangi kekhidmatan jalannya upacara adat yang suci ini.

\section{Sakral}

Sebagian orang percaya Bedhaya Ketawang ini dipandang sebagai suatu tarian ciptaan ratu di antara seluruh makhluk halus. Bahkan mereka percaya bahwa setiap kali Bedhaya Ketawang ditarikan, sang pencipta selalu hadir juga dan ikut menari. Tidak setiap orang dapat melihatnya, 48 hanya pada mereka yang peka saja sang pencipta ini menampakkan diri. Konon, dalam latihan-latihan yang dilakukan sering pula sang pencipta ini membenarkan kesalahan yang dibuat oleh sang penari. Bila omata orang awam tidak melihatnya maka penari yang bersangkutan saja yang bisa merasakan.

\section{Religius}

Segi religius tari Bedhaya Ketawang dapat dilihat dpat dilihat dari kata-kata yang dinyanyikan oleh suarawatinya. Antara lain ada yang berbunyi :.....tanu astra kadya agni urube, kantar-kantar kyai ,......yen

mati ngendi urube, kyai ? (.......kalau mati kemana tujuannya kyai ?)

\section{Tari percintaan atau tarian perkawinan}

Tari Bedhaya Ketawang melambangkan curahan cinta asmara Kangjeng Ratu Kidul kepada Sinuhun Sultan Agung. Semuanya itu terlukis dalam gerak-gerik tangan serta seluruh bagian tubuh, cara memegang sondher dan lain sebagainya. Namun demikian cetusan segala lambang tersebut telah dibuat demikian halusnya, hingga mata awam kadang-kadang sukar memahaminya. Satu-satunya yang jelas dan memudahkan dugaan tentang adanya hubungan dengan suatu perkawinan adalah bahwa semua penarinya dirias sebagaimana lazimnya mempelai akan dipertemukan. Tentang kata-kata yang tercantum dalam nyanyian yang mengiringi tarian, jelas menunjukkan gambaran curahan asmara Kangjeng Ratu yang merayu Sunuhun. Bila ditelaah dan dirasakan maka
49 menurut penilaian dan pandangan masa kini mungkin dianggap kurang senonoh sebab sangat membangkitkan rasa birahi.

Berkaitan dengan itu, Hadiwidjojo (2004:14) menjelaskan bahwa aslinya pergelaran ini berlangsung selama 2,5 jam. Tetapi sejak jaman Sinuhun Paku Buwono $\mathrm{X}$ diadakaan pengurangan, hingga akhirnya menjadi 1.5 Jam saja. Bagi mereka yang secara langsung atau tidak langsung terlibat dalam kegiatan yang khudus ini berlaku suatu kewajiban khusus. Sehari sebelumnya para anggota kerabat Sinuhun menyucikan diri,lahir, dan batin. Peraturan ini di masa-masa dahulu ditaati benar. Walaupun dirasa sangat memberatkan dan menyusahkan,namun berkat kesadaran dan ketaatan serta pengabdian pada keagungan Bedhaya Ketawang yang khudus itu, segala peraturan tersebut dilaksanakan juga dengan penuh tulus ikhlas. Yang penting ialah bahwa bagi mereka ini Bedhaya Ketawang merupakan suatu pusaka yang suci. Untuk inilah mereka semua mematuhi setiap peraturan tatacara yang berlaku. Bagi para penari ada peraturan yang lebih ketat lagi, sebab menurut adat kepercayaan, mereka ini langsung berhubungan dengan Kanjeng Ratu Kidul. Karena itu mereka juga selalu harus dalam keadaan suci, baik pada masa-masa latihan maupun pada waktu pergelarannya. Sebagai telah diketemukan d depan, Kanjeng Ratu Kidul hanya dapat dirasakan kehadirannya oleh mereka yang langsung disentuh atau dipegang, bila cara menarinya masih kurang betul. Oleh karena itu, pada setiap latihan yang diadakan pada hari-hari Anggrakasih (Selasa Kliwon), setiap penari dan semua pemain gamelan beserta suarawatinya harus elalu dalam keadaan suci. Persiapan-persiapan untuk suatu pergelaran Bedhaya Ketawang harus dilakukan sebaik-baiknya, dengan sangat teliti. Bila ada yang merasa menghadapi halangan bulanan, lebih baik tidak mendaftarkan diri dahulu. Di samping sejumlah penari yang diperlukan selalu diadakan juga penari-penari cadangan. 
Bagi para penari ada beberapa pantangan yang harus diperhatikan. Karena itu dipandang lebih bijaksana untuk memilih penari-penari yang sudah cukup dewasa jiwanya, sehingga kekhusukan dan ketekunan menarinya akan lebih dapat terjamin. Keseluruhannya ini akan menambah keagungan suasananya.

Tuti hariyani, (2007, 49-51) mengemukakan seiring perkembangan zaman yang semakin modern, tentunya sangat dipengaruhi kehidupan manusia. Begitu juga Bedhaya Ketawang yang sifatnya tradisional, sekarang sudah mengalami pergeseran. Hal ini sebagai bukti bahwa sifat kebudayaan akan senantiasa berubah setiap kurun waktu walaupun unsur aslinya akan tetap bertahan. Tari Bedhaya Ketawang telah mengalami pergeseran. Pergeseran itu antara lain:

\section{a. Adat Seremonial}

Dalam penyelenggaraan yaitu suatu pertunjukan resmi dalam menggambarkan keagungan ulang tahun jumenengan kenaikan tahta Sri Susuhunan, jadi hanya disaksikan kerabat keraton saja. Tetapi pada tahun 1920 mulailah dilihat oleh tamu yaitu Residen Harloff bersama para pengikutnya pembesar sipil atau militer. mereka diundang untuk memberikan ucapan selamat kepada Sri Susuhunan dan meminta izin untuk diperbolehkan menyaksikan tari Bedhaya Ketawang. Terbukti pada saat peringatan kenaikan tahta raja Paku Buwono XIII dihadiri para tamu undangan baik pejabat pemerintahan maupun tamu agung dari kerajaan asing. Mereka yang tidak diundang juga diperkenakan hadir apabila ingin menyaksikan Bedhaya Ketawang tetapi dengan izin keraton. Seperti penulis sendiri yang dapat menyaksikan tari Bedhaya Ketawangdengan seizin pihak keraton.

b. Ketentuan Penari

$$
\text { Mengingat isi cerita Bedhaya }
$$

Ketawang mengandung percintaan antara Panembahan Senopati dengan Kanjeng Ratu Kidul, maka pembawa tarian itu bukanlah putri raja, melainkan para abdi dalem bedhaya.
Peraturan pada zaman dulu sangat ketat sekali tapi sekarang sudah berubah. Mulai Paku Buwono XII tepatnya tahun 1988 peraturan tersebut tidak lagi dijadikan patokan. Terbukti putri Sinuhun yaitu G.R.A.Y Koes Murtiyah sebagai penari Bedhaya Ketawang(pada saat belum menikah) dan memerankan sebagai Batak (pemimpin tari) dan sekarang menjadi pelatihnya. Sekarang orang dari luar keraton pun diperbolehkan menjadi penari Bedhaya Ketawangdengan syarat diizinkan oleh keraton. Hal ini dilakukan demi kelestarian tari Bedhaya Ketawangitu sendiri mengingat para kerabat keraton saat ini banyak yang tinggal di luar keraton. Pada zaman dulu, para penari tidak diperbolehkan menari jika dalam keadaan haid. Tetapi sekarang diperbolehkan asal dimintakan izin dulu pada Kanjeng Ratu Kidul (G.R.Ay Koes Murtiyah, wawancara 23 Maret 2007).

c.Lama Pementasan

Sebelum masa pemerintahan Paku Buwono X, lama pementasan Bedhaya Ketawang adalah dua setengah jam dan latihan dimulai pada pukul 10.00. Setelah Paku Buwono $X$, lama pementasn diperpendek menjadi satu setengah jam dan latihan dimulai latihan pukul 13.00. Alasan pementasan diperpendek dikemukakan oleh G.R.A Koes Murtiyah yaitu, jika dua setengah jam, pathetanmana lagi yang akan dipakai. Larangan pengambilan gambar pada zaman dulu juga ditabukan, karena hanya akan mengurangi kesakralan yang terkandung dalam tari Bedhaya Ketawang. Tapi sekarang dengan kemajuan teknologi diperbolehkan mengambil gambar untuk dokumentasi.

Dengan adanya perubahan-perubahan tersebut di atas, maka makna yang terkandung dalam tari Bedhaya Ketawang pun juga ikut berubah dan bergeser. Pergeseran-pergeseran itu adalah :

1.Pergeseran makna kebesaran dan kehormatan.

Makna kebesaran dan kehormatan dalam tari Bedhaya Ketawangtelah mengalami 
suatu pergeseran yang cukup besar. Hal ini dikarenakan kedudukan dan fungsi keraton tempat tumbuh dan berkembangnya Bedhaya Ketawangtelah mengalami perubahan dalam ketatanegaraan dan politik di Indonesia. Walaupun masyarakat di sekitar keraton menganggap raja masih berperan dalam berbagai aspek kehidupan, tapi bagi masyarakat secara umum menganggap raja hanya sebagai pemimpin adat di wilayah Surakarta.

2.Pergeseran makna kekhusukan.

Makna kekhusukan dalam tari Bedhaya Ketawang juga telah mengalami pergeseran. Pada saat penulis menyaksikan latihan Bedhaya Ketawang, para penari tampak menari dengan terkesan biasa saja. Bahkan di antara mereka ada yang menggaruk-garuk kepala pada saat menari. Para penari akan terlihat serius pada saat acara pementasan. Dari sini dapat disimpulkan bahwa kekhusukan para penari disebabkan oleh penonton dan bukan karena adanya kesadaran dari penari bahwa itu merupakan tarian sakral yang harus dibawakan dengan keseriusan. Para peserta acara Tingalandalem Jumenengan saat menyaksikan tari Bedhaya Ketawangjuga juga terkesan biasa saja dan seolah olah tidak memperhatikan. Para tamu dan abdi dalem pun ada yang makan, minum atau merokok. Melihat kenyataan ini sangat berbeda sekali dengan apa yang penulis baca pada buku-buku mengenai kesakralan tari ini.

\section{Pergeseran makna ritual.}

Pergeseran makna ritual terlihat pada para penari pada saat akan mementaskan tari Bedhaya Ketawang tidak melakukan ritual puasa seperti yang dilakukan para penari terdahulu. Ritual puasa dilakukan untuk membersihkan hati dan pikiran supaya pada saat pementasan mudah berkonsentrasi.

Suharji (2015:35) menyatakan bahwa Tari Bedhaya adalah salah satu tarian putri yang bersifat simbolik yang berkembang di Kraton Surakarta. Tari Bedhaya pada jaman kerajaan merupakan kelengkapan kebesaran seorang raja serta menjadi lambang kekuasaan keraton Surakarta. Tari Bedhaya diperagakan oleh sembilan penari yag berbusana, tata rias, serta gerak tarian yang cenderung lembut, dan menggambarkan sebuah cerita. Masing-masing penari mempunyai nama-nama tertentu di dalam komposisinya yaitu endel ajeg, batak, gulu, dhada, apit ngarep, apit mburi, apit meneng, edhel weton, dan terakhir buncit, simbolis dari sembilan nafsu manusia

Robert Von Heine Gelden dalam (Hadiwijaya, 2001:84) menjelaskan bahwa dalam upacara-upacara atau ritus kerajaan yang bersifat sakral dengan menghadirkan tari Bedhaya, tari berfungsi sebagai alat kebesaran raja, sama dengan alat-alat kebesaran yang lain memiliki kekuatan magis seperti berbagai macam senjata, payung kebesaran, mahkota, dan benda-benda lainnya. Bedhaya dan bendabenda dengan kekuatan magis yang terkandung di dalamnya berfungsi sebagai realigia atau pusaka kerajaan yang senantiasa turut memperkokoh maupun memberi perlindungan, ketenteraman, kesejahteraan kepada raja dan seluruh kawunya. Kepercayaan seperti inilah memiliki makna peranan kosmis raja, istana dan pemerintahannya, yakni kesejajaran antara mikrokosmos dan makrokosmos. Artinya istana sebagai mikrokosmos berusaha mencari keselarasan, keserasian maupun keharmonisan kehidupan dengan makrokosmos, yaitu mengharapkan kelanggengan untuk mencapai kesejahteraan dan kemakmuran kerajaan.

Mencermati adanya pergeseran di beberapa hal dalam tarian bedhaya Ketawang merupakan hal yang tidak bisa dihindari. Pergeseran tersebut menjadikan Tari Bedhaya Ketawang menjadi hidup ditengah-tengah masyarakat.Tari Bedhaya ketawang menjadi aset budaya yang harus dilestarikan dan diuriuri keberadaannya.

1. Adat Upacara

Mulai dari pertunjukan ketika di dalam istana hanya disajikan pada saat jumenengan raja saja. Selain jumenengan raja, tarian ini 
tidak boleh dipentaskan. Setelah mengalami berbagai hal dan pertimbangan akhirnya Tari Bedhaya Ketawang dapat dipentaskan di luar kraton. Akan tetapi setelah diperbolehkan dipertunjukan di luar kraton sekarang Tari Bedhaya Ketawang boleh dipentaskan pada event-event kebudayaan maupun nonkebudayaan. Seperti di ISI Surakarta sering mementaskan tari Bedhaya Ketawang pada saat upacara Wisuda, Dies Natalis, dan sebagainya. Seringkali berbagai event budaya yang diselenggarakan di kota Surakarta juga menjamu para tamu dengan mementaskan Tari Bedhaya Ketawang.

\section{Sakral}

Tari Bedhaya Ketawang memiliki nilai kesakralan yang masih terasa. Meskipun tidak semua orang bisa merasakan akan tetapi jika ada yang peka pada saat dipentaskan akan terasa nuansa mistisnya. Pada waktu masih dipentaskan hanya pada saat jumenengan hanya undangan tertentu yang bisa melihat. Raja biasanya hanya mengundang orang-orang yang terhormat saja. Para undangan pun dengan khitdmat menyaksikan pertunjukan tanpa dengan bicara, merokok dan sebagainya. Akan tetapi sekarang tarian ini dipertujukan secara umum. Orang awam pun hanya tahu bahwa Tari Bedhaya Ketawang hanyalah sebuah tarian yang mana fungsinya sebagai salah satu hiburan. Sehingga mereka pun biasa melihat pertunjukan dengan berbicara, merokok, ataupun dengan aktivitas lainnya. Nilai kesakrakalannya pun sudah tidak bisa ditemukan lagi.

\section{Ketentuan penari}

Tari Bedhaya Ketawang pada saat masih di pertunjukan di dalam kraton hanya boleh dibawakan oleh penari yang betul-betul memenuhi kriteria saja. Misalnya Tari Bedhaya Ketawang hanya boleh ditarikan hanya pada seorang gadis yang masih perawan. Selain masih perawan juga pada saat menari tidak dalam kondisi haid. Jumlah penari Bedhaya Ketawang ada 9. Untuk sekarang ini, Tari Bedhaya Ketawang boleh ditarikan oleh semua wanita. Jika sedang haid ada syarat tertentu yang harus dipenuhi, yaitu meminta ijin dahulu. Jumlah penari masih tetap 9 .

\section{Waktu pertunjukan}

Sebelum masa pemerintahan Paku Buwono X, lama pementasan Bedhaya Ketawang adalah dua setengah jam dan latihan dimulai pada pukul 10.00. Setelah Paku Buwono X, lama pementasn diperpendek menjadi satu setengah jam dan latihan dimulai latihan pukul 13.00. Sekarang waktu pementasan Tari Bedhaya Ketawang bisa berdurasi hanya setengah jam atau satu jam saja tergantung pada kepadatan acaranya. Sehingga tidak seperti di istana yang memiliki durasi waktu yang sudah pakem. Ada beberapa gerakan dalam tari Bedhaya Ketawang yang sudah dihilangkan untuk pertunjukan sekarang. Biasanya adengan yang dilakukan berulang-ulang dapat dipadatkan.

Melihat dari paparan di atas dapat dipahami bahwa pergeseran dalam sajian Tari bedhaya ketawang merupakan hal yang tidak bisa dihindari. Pergeseran dalam Tari Bedhaya Ketawang ternyata malah membawa perkembangan Tari Bedhaya Ketawang dapat dikenal di di masyarakat umum. Sehingga dapat dipelajari di masyarakat dan dikenal secara luas menjadi aset budaya.

\section{SIMPULAN}

Tari Bedhaya Ketawang merupakan tarian yang dikembanggkan di Kraton Surakarta. Bedhaya Ketawang adalah tarian yang hanya disajikan untuk Raja di Kraton Surakarta dengan jumlah penari 9. Sedangkan rakyat boleh menarikan dengan jumlah penari 7 orang. Penarinya pun haruslah seorang gadis yang suci tidak sedang haid. Tarian Bedhaya Ketawang merupakan suatu tarian yang berfungsi tidak hanya sebagai hiburan, karena tarian ini hanya ditarikan untuk sesuatu yang khusus dan dalam suasana yang sangat resmi. Tari Bedhaya Ketawang menggambarkan hubungan asmara Kangjeng Ratu Kidul dengan raja-raja Mataram. Tari Bedhaya Ketawang 
ini dipertunjukkan maka dipercaya Kangjeng Ratu Kidul akan hadir dalam upacara dan ikut menari sebagai penari ke sepuluh. Tari Bedhaya Ketawang ini dibawakan oleh sembilan penari. Dalam mitologi Jawa, sembilan penari Bedhaya Ketawang menggambarkan sembilan arah mata angin yang dikuasai oleh sembilan dewa yang disebut dengan Nawasanga. Sementara, versi lain menyebutkan bahwa jumlah penari yang sembilan orang merupakan lambang dari Sembilan Wali atau Wali Songo.

Tari Bedhaya Ketawang dipertunjukan di dalam istana hanya pada saat jumenengan raja saja. Selain jumenengan raja, tarian ini tidak boleh dipentaskan. Setelah mengalami berbagai hal dan pertimbangan akhirnya Tari Bedhaya Ketawang dapat dipentaskan di luar kraton. Akan tetapi setelah diperbolehkan dipertunjukan di luar kraton sekarang Tari Bedhaya Ketawang boleh dipentaskan pada event-event kebudayaan maupun nonkebudayaan. Seperti di ISI Surakarta sering mementaskan tari Bedhaya Ketawang pada saat upacara Wisuda, Dies Natalis, dan sebagainya. Seringkali berbagai event budaya yang diselenggarakan di kota Surakartajuga menjamu para tamu dengan mementaskan Tari Bedhaya Ketawang. Tari Bedhaya Ketawang memiliki nilai kesakralan yang masih terasa. Meskipun tidak semua orang bisa merasakan akan tetapi jika ada yang peka pada saat dipentaskan akan terasa nuansa mistisnya. Pada waktu masih dipentaskan hanya pada saat jumenengan hanya undangan tertentu yang bisa melihat. Raja biasanya hanya mengundang orang-orang yang terhormat saja. Para undangan pun dengan khitdmat menyaksikan pertunjukan tanpa dengan bicara, merokok dan sebagainya. Akan tetapi sekarang tarian ini dipertujukan secara umum. Orang awam pun hanya tahu bahwa Tari Bedhaya Ketawang hanyalah sebuah tarian yang mana fungsinya sebagai salah satu hiburan. Sehingga mereka pun biasa melihat pertunjukan dengan berbicara, merokok, ataupun dengan aktivitas lainnya. Nilai kesakrakalannya pun sudah tidak bisa ditemukan lagi.Tari Bedhaya Ketawang pada saat masih di pertunjukan di dalam kraton hanya boleh dibawakan oleh penari yang betul-betul memenuhi kriteria saja. Misalnya Tari Bedhaya Ketawang hanya boleh ditarikan hanya pada seorang gadis yang masih perawan. Selain masih perawan juga pada saat menari tidak dalam kondisi haid. Jumlah penari Bedhaya Ketawang ada 9. Untuk sekarang ini, Tari Bedhaya Ketawang boleh ditarikan oleh semua wanita. Jika sedang haid ada syarat tertentu yang harus dipenuhi, yaitu meminta ijin dahulu. Jumlah penari masih tetap 9 untuk masa itu. Sedangkan, untuk rakyat hanya boleh ditarikan 7 orang. Sebelum masa pemerintahan Paku Buwono X, lama pementasan Bedhaya Ketawang adalah dua setengah jam dan latihan dimulai pada pukul 10.00. Setelah Paku Buwono X, lama pementasn diperpendek menjadi satu setengah jam dan latihan dimulai latihan pukul 13.00. Sekarang waktu pementasan Tari Bedhaya Ketawang bisa berdurasi hanya setengah jam atau satu jam saja tergantung pada kepadatan acaranya . Sehingga tidak seperti di istana yang memiliki durasi waktu yang sudah pakem. Ada beberapa gerakan dalam tari Bedhaya Ketawang yang sudah dihilangkan untuk pertunjukan sekarang. Biasanya adengan yang dilakukan berulangulang dapat dipadatkan. 


\section{Kepustakaan}

Dharsono. 2015. Buku Ajar. Estetika Nusantara. Surakarta: ISI Press

Hawkins, Alma M. 1991. Moving From Within : A New Method For Dance Marking. Chicago: A Capelia Books.

Hariyani, Tuti .2007. Pergeseran Makna Tari Bedhaya Ketawang di Keraton Surakarta Hadiningrat Dari Tahun 19202005. Semarang:Unessa. Skripsi :tidak dipublikasikann $\mathrm{S}$

James R. Brandon.1967. Theatre in Southeast Asia. Cambrigde: Harvad University Press.

Koentjaraningrat. 1984. Kebudayaan Jawa. Jakarta: Balai Pustaka. 1985. Ritus Peralihan di Indonesia. Jakarta : Balai Pustaka

Maryono. 2012. Analisa Tari. Surakarta : ISI Press.

Paku Buwono XII. 1992. Harapan Keraton Surakarta Hadiningrat kepada Masyarakat Masa Kini. Seminar Kebudayaan.
Purwadi dan Djoko Dwiyanto. 2009. Kraton Surakarta. Yogyakarta : Panji Aksara.

Sari, Siska Ratna. 2010. Bedhaya Ketawang (Studi Nilai Filosofofis Tari Bedhaya Ketawang.

Surakarta: UNS. Skripsi : Tidak dipublikasikan Soemaryatmi. 2007. Wirama Tunggal. Tari Gaya Yogyakarta. Surakarta : ISI Press

Soedarsono, R.M.1987.Pengantar Pengetahuan dan Komposisi Tari. Yogyakarta : ASTI

Sutrisno, Muji. Makalah. 2010. Seni itu (Demi) Merawat Kehidupan. Surakarta :ISI Press

Sutarno Haryono.2013. Pengetahuan Tari. Surakarta : ISI Press.

Suharji. 2004. Bedhaya Suryasumirat. Semarang : Intra Pustaka Utama.

Tasman, A. 2008. Analisa Gerak dan Karakter. Surakarta : ISI Press.

Wiedyastutiningrum, Sri Rochana. 2011. Sejarah Tari Gambyong. Surakarta : ISI Press, Sri Rochana dan Dwi Wahyudiarto. 2014. Pengantar Koreograf : ISI Surakarta.

Koreografi I. Buku Ajar. 